\title{
KUALITAS KEHIDUPAN SEKOLAH DAN DISIPLIN PADA SANTRI ASRAMA PONDOK PESANTREN
}

\section{QUALITY OF SCHOOL LIFE AND DISCIPLINE ON ISLAMIC BOARDING SCHOOL STUDENTS}

\author{
Nikmah Sofia Afiati \\ Universitas Mercu Buana Yogyakarta \\ afi@mercubuana-yogya.ac.id
}

\begin{abstract}
Abstrak
Penelitian ini bertujuan untuk mengetahui hubungan antara kualitas kehidupan sekolah dengan disiplin pada santri asrama pondok pesantren. Hipotesis yang diajukan dalam penelitian ini adalah terdapat hubungan positif antara kualitas kehidupan sekolah dengan disiplin pada santri asrama pondok pesantren. Subjek penelitian yaitu santri asrama di Pondok Pesantren Pabelan yang berjumlah 140 orang. Alat pengumpul data dalam penelitian ini adalah skala disiplin $(\alpha=0,915)$ dan skala kualitas kehidupan sekolah $(\alpha=0,903)$ yang telah diujicobakan pada 78 santri asrama. Data yang diperoleh berdasarkan hasil analisis regresi linier sederhana menunjukkan nilai koefisien korelasi sebesar 0,508 dan $\mathrm{p}=0,000(\mathrm{p}<0,01)$, artinya terdapat hubungan yang positif antara kualitas kehidupan sekolah dengan disiplin pada santri asrama pondok pesantren, sehingga hipotesis yang diajukan dapat diterima. Sumbangan efektif kualitas kehidupan sekolah terhadap disiplin sebesar 25,8\%, sedangkan $74,2 \%$ dipengaruhi oleh faktor lain.
\end{abstract}

Kata Kunci: kualitas kehidupan sekolah, disiplin, santri asrama

\begin{abstract}
This study aims to determine the relationship between the quality of school life with discipline in Islamic boarding school students. The hypothesis proposed in this study is that there is a positive relationship between the quality of school life and discipline in Islamic boarding school students. The participants of the study were 140 Islamic boarding school students in Pondok Pesantren Pabelan (Pabelan Islamic Boarding School). The data collection tool in this research is the discipline scale ( $\alpha$ $=0,915)$ and the scale of school life quality $(\alpha=0,903)$ which have been tested in 78 boarding students at Pondok Pesantren Pabelan. The data obtained based on the results of simple linear regression analysis showed the value of $r=0.508$ and $p=0.000(p<0.01)$, this indicates a positive relationship between quality of school life and discipline in Islamic boarding school students, so the hypothesis can be accepted. The effective contribution of quality of school life to discipline is 25.8\%, while $74.2 \%$ is influenced by other factors.
\end{abstract}

Keywords: quality of school life, discipline, boarding school students

\section{PENDAHULUAN}

Disiplin merupakan salah satu unsur kualitas sumber daya manusia. Disiplin dapat membuat seseorang memiliki perasaan taat dan patuh terhadap nilai yang diyakini sehingga lebih bertanggung jawab untuk dapat mengatur tatanan kehidupan pribadi dan kelompok (Djamarah, 2008). Disiplin juga menjadi sarana pendidikan yang berperan mempengaruhi, 
mendorong, mengendalikan, mengubah, membina, dan membentuk perilaku-perilaku tertentu sesuai dengan nilai-nilai yang ditanamkan, diajarkan, dan diteladankan. Disiplin dapat membuat siswa memiliki pola hidup yang teratur berdasarkan nilai agama, nilai budaya, aturan pergaulan, pandangan hidup, serta sikap hidup yang bermakna untuk dirinya sendiri (Sochib, 2010). Sebaliknya, disiplin yang belum terbina dengan baik dapat berdampak negatif terhadap pendidikan.

Pemerintah Indonesia sejak tahun 2010 telah mencanangkan program pendidikan karakter bangsa, dan ditegaskan kembali dalam pidato presiden pada peringatan hari pendidikan nasional 2 Mei 2010. Program tersebut dicanangkan dengan sebab kondisi bangsa yang menunjukkan semakin memudarnya nilai-nilai luhur bangsa Indonesia dalam sikap dan perilaku masyarakatnya (Huda, 2014). Disiplin sebagai salah satu aspek pribadi dan karakter merupakan hal yang perlu diperhatikan dan tidak boleh diabaikan (Blandford, 2005).

Sekolah sebagai lembaga pendidikan yang sangat strategis untuk menanamkan dan mengajarkan kedisiplinan dirasa perlu untuk meningkatkan upaya dalam penegakan disiplin. Oleh karena itu kepala sekolah dan guru-guru perlu menempatkan disiplin ke dalam prioritas program pendidikan di sekolahnya (Blandford, 2005). Guru juga harus memperhatikan siswanya dengan baik dan tidak hanya berorientasi pada selesainya penyampaian materi pelajaran di kelas. Dengan demikian siswa akan terbawa arus disiplin sekolah yang baik sehingga diharapkan akan melahirkan siswa-siswa yang berperilaku positif serta berprestasi baik (Rogers, 2011).

Setiap sekolah memiliki kebijakan terkait penanaman dan penegakan disiplin untuk para siswanya (Blandford, 2005), begitu juga dengan pondok pesantren. Sistem pendidikan dan pembelajaran di pesantren menekankan pelajaran agama Islam dan didukung asrama sebagai tempat tinggal santri yang bersifat permanen (Qomar, 2006). Salah satu ciri khas sistem pendidikan yang dikembangkan dalam sebuah pesantren yaitu penerepan sistem disiplin yang lebih ketat untuk para siswanya dibanding sekolah umum (Handayani, 2007), sementara peran pesantren dalam kehidupan para santri berkaitan dengan moral-moral dan nilai-nilai sosial agama yang ditanamkan melalui peraturan, pelajaran, serta bimbingan yang ada di pesantren (Handayani, 2007). Sebagai salah satu cara dalam menanamkan disiplin pada santri, penerapan peraturan di pesantren ditunjukkan dengan adanya kewajiban santri untuk tinggal di asrama atau berada di lingkungan pesantren selama 24 jam dan seluruh kegiatannya diatur oleh pihak pesantren, baik kegiatan harian maupun mingguan (Mu'tasim, 2005). 
Penerapan peraturan di pesantren ternyata tidak menjadi jaminan bahwa disiplin dapat terwujud dengan baik. Pada kenyataannya masih banyak pelanggaran yag dilakukan siswa baik ketika jam sekolah maupun ketika mengikuti kegiatan di asrama. Keterbatasan dalam pengawasan dari pihak pesantren menjadi salah satu penyebabnya. Hasil wawancara peneliti pada Februari 2012 kepada pengasuh di lingkungan pesantren menunjukkan bahwa santri asrama di Pondok Pesantren Pabelan rentan dengan keadaan rendah pengawasan karena jumlah ustadz dan ustadzah yang terbatas. Pihak pesantren sendiri tidak mampu untuk melakukan pengawasan dan kontrol secara maksimal terhadap santrinya sehingga sering terjadi pelanggaran.

Hasil wawancara yang dilakukan peneliti pada Februari 2012 terhadap empat orang santri di area asrama Pondok Pesantren Pabelan menunjukkan hal senada, yaitu bahwa pelanggaran-pelanggaran peraturan dan tata tertib ternyata masih berlangsung baik di asrama maupun dalam kegiatan belajar-mengajar di kelas. Pelanggaran-pelanggaran tata tertib yang masih banyak dijumpai pada santri asrama misalnya keluar asrama tanpa meminta ijin, kasus pencurian kecil, terlambat masuk kelas, membolos pada jam pelajaran, mengenakan pakaian seragam tidak sesuai dengan aturan, tidur di kelas, berpacaran antara santri putra dan santri putri, merokok di lingkungan pesantren, membuang sampah sembarangan, perkelahian, dan tidak melaksanakan piket baik di kelas maupun di asrama. Setiap pelanggaran yang dilakukan akan mendapatkan sanksi sesuai dengan peraturan sekolah atau asrama, meskipun demikian, empat santri yang menjadi responden mengaku tetap saja tidak jera melakukan pelanggaran, terutama ketika ada kesempatan terhindar dari pengawasan pengurus, ustadz, maupun kyai. Banyaknya pelanggaran yang dilakukan menunjukkan masih rendahnya disiplin pada santri di lingkungan pesantren.

Permasalahan terkait rendahnya disiplin pada siswa juga diperkuat dengan masih banyaknya penelitian yang berusaha menggunakan strategi atau teknik tertentu untuk meningkatkan disiplin pada siswa. Strategi yang dilakukan di antaranya pemberlakuan aturan yang semakin ketat di sekolah (Rahman, 2016), pemberian sanksi (Triastuti, 2015), kegiatan tambahan seperti kepramukaan untuk meningkatkan kedisiplinan (Setyorini, 2016; Zulbina \& Sailan, 2015), memberikan pelatihan kedisiplinan untuk meningkatkan disiplin belajar (Dewi, 2010), konseling kelompok untuk meningkatkan disiplin (Yudiastri, Yusmansyah, \& Rahmayanthi, 2015), hingga melibatkan peran orangtua dalam pembiasaan dan penanganan masalah kedisiplinan (Nurhasan \& Suyanto, 2014; Wahyuni, 2012).

Disiplin pada dasarnya mengacu pada belajar dengan berfokus pada pengembangan kontrol diri melalui pengajaran keterampilan pemecahan masalah dan belajar cara yang lebih 
produktif untuk mengungkapkan perasaan (Dupper, 2010). Disiplin merupakan suatu kondisi yang tercipta dan terbentuk melalui proses dari serangkaian perilaku yang menunjukkan nilai-nilai ketaatan, kepatuhan, kesetiaan, keteraturan, dan atau ketertiban (Prijodarminto, dalam Atifah, 2006; Djojonegoro, dalam Soemarmo, 1998). Disiplin di sekolah diterapkan bukan sebagai usaha untuk membuat siswa menahan tingkah laku yang tidak diterima oleh sekolah, melainkan sebagai usaha untuk memperkenalkan cara atau memberikan pengalaman yang akhirnya membawa siswa kepada pemilikan suatu disiplin yang timbul dari dirinya sendiri (Bagley, 2010).

Djojonegoro (dalam Soemarmo, 1998) menyatakan bahwa disiplin pada tingkat individu terdiri dari tiga aspek, yaitu pemahaman yang baik mengenai sistem aturan dan norma yang menumbuhkan kesadaran dan ketaatan pada aturan, norma, kriteria, dan standar yang merupakan syarat untuk mencapai keberhasilan (sukses), sikap mental (mental attitude) yang merupakan sikap taat dan tertib sebagai hasil atau pengembangan dari latihan, pengendalian pikiran, dan pengendalian watak, serta kecenderungan perilaku yang secara wajar menunjukkan kesungguhan hati untuk mentaati segala hal secara cermat dan tertib.

Disiplin dipengaruhi oleh faktor eksternal dan internal (Dupper, 2010; Djojonegoro, dalam Soemarmo 1998). Faktor eksternal dapat bersumber dari lingkungan tempat individu berada, baik lingkungan keluarga, sekolah, maupun masyarakat. Faktor internal yaitu dipengaruhi kondisi fisik, perkembangan, dan psikologis yang mendorong perilaku siswa disertai konsekuensi yang mungkin terjadi atas perilakunya tersebut. Salah satu faktor internal dari sisi kondisi psikologis yang mempengaruhi disiplin pada siswa yaitu penilaian terhadap pengalaman selama di sekolah. Pengalaman negatif yang diperoleh siswa dan membuatnya kurang nyaman dapat berimbas langsung kepada kondisi psikologis. Gridner (dalam Octyavera, 2006) menyatakan bahwa interaksi di dalam keluarga, sekolah, dan masyarakat merupakan faktor yang berpengaruh pada perkembangan diri seseorang. Jika berpengaruh secara negatif maka siswa merasa enggan melakukan interaksi aktif dan intensif terhadap lingkungan sosialnya. Siswa cenderung menarik diri dan tidak tertarik untuk menampilkan perilaku positif di dalamnya.

Johnson and Johnson (1993) melaporkan bahwa kualitas pengalaman yang diperoleh di sekolah berpengaruh pada sikap dan perilaku siswa serta persepsi positif siswa terhadap sekolah. Aktivitas di dalam kelas dan interaksi dengan guru juga merupakan hal yang penting untuk kesehatan mental siswa dan dapat meningkatkan target pencapaian sekolah. Persepsi, perasaan, dan sikap negatif siswa terhadap sekolah akan menyebabkan ketidakpuasan siswa dalam kehidupan sehari-hari di sekolah dan menimbulkan hambatan 
dalam belajar. Persepsi siswa terhadap kualitas dari berbagai aspek sosial, aspek formal, dan informal dari sekolah, pengalaman yang berhubungan dengan tugas, dan hubungan individu dengan figur otoritas dan dengan teman-teman di sekolah ini yang kemudian didefinisikan sebagai quality of school life atau kualitas kehidupan sekolah (Leonard, 2002) .

Epstein and McPartland (1976, dalam Thien \& Razak, 2012) sebagai tokoh yang mempelopori penelitian mengenai kualitas kehidupan sekolah mendefinisikannya sebagai suatu pengukuran yang dipengaruhi oleh aspek formal dan informal dari sekolah, seperti pengalaman yang berkaitan dengan sosial dan tugas, hubungan dengan figur yang memiliki otoritas maupun dengan teman. Penelitian selanjutnya oleh Williams and Batten (1981, dalam Thien \& Razak, 2012) mendefinisikan kualitas kehidupan sekolah sebagai keseluruhan perasaan kebahagiaan, kesejahteraan, atau kepuasan yang ditunjukkan dalam suatu kondisi. Karatzias, Power, dan Swanson (2002) menyebutkan bahwa kualitas kehidupan sekolah merupakan perasaan sejahtera secara umum yang dihasilkan dari keterlibatan siswa dalam kehidupan di sekolah dan keterikatannya di sekolah. Malin dan Linnakyla (dalam Weintraub \& Erez, 2009) senada menjelaskan bahwa kualitas kehidupan sekolah merupakan derajat kesejahteraan dan kepuasan siswa secara umum pada kehidupan di sekolahnya berdasar pandangan siswa terhadap pengalaman positif dan pengalaman negatif di sekolah dan aktivitas-aktivitas yang dilakukan siswa di sekolah.

Lima dimensi spesifik dari kualitas kehidupan sekolah menurut William \& Batten (dalam Kwong, 2006) serta Ainley \& Bourke (dalam Leonard, 2002) meliputi (a) Teacher (hubungan guru-siswa), mengacu pada kepuasan siswa terhadap hubungannya dengan guru di sekolah; (b) Opportunity (peluang menghadapi masa depan), mengacu pada harapan siswa terhadap relevansi sekolah di masa yang akan datang, dan keyakinan bahwa sekolah akan membuka peluang bagi masa depannya; (c) Achievement (perasaan berprestasi di sekolah), mengacu pada perasaan berprestasi siswa yang diperoleh dari sekolah; (d) Social integration (integrasi sosial), mengacu pada perasaan siswa terhadap kehidupan sosialnya di sekolah dan peran sekolah dalam mengembangkan keterampilan tersebut; dan (e) Adventure (petualangan dalam pembelajaran), mengacu pada tingkat kenyamanan dan kesenangan yang dirasakan siswa dalam beraktivitas dan mengerjakan tugas di sekolah.

Terkait dimensi hubungan guru dan siswa, hasil penelitian Sen Keung Pang (dalam Kwong, 2006) di Hongkong menemukan bahwa hubungan guru dan siswa yang baik dapat mempertahankan kualitas kehidupan sekolah. Guru yang empatik, menghargai, konsisten, dan memiliki harapan yang jelas terhadap siswa lebih membuat siswa merasa terhubung dan terlibat dalam ruang kelas (Dupper, 2010). Siswa yang memiliki pengalaman-pengalaman 
positif di sekolah hanya memiliki sedikit perasaan negatif terhadap sekolah, sebaliknya, siswa yang memiliki pengalaman-pengalaman negatif di sekolahnya akan semakin mengembangkan perasaan negatif terhadap sekolah. Perasaan negatif akan membuat siswa enggan untuk berinteraksi dengan sekolah dan enggan untuk melakukan perilaku disiplin di sekolah, sebaliknya, perasaan positif akan membuat siswa bersemangat untuk sekolah dan bersedia untuk melakukan perilaku disiplin terhadap sistem, aturan, dan berbagai kondisi yang ada di sekolah.

Kualitas kehidupan sekolah yang yang dimiliki secara positif oleh siswa menunjukkan pandangan dan perasaan yang positif terhadap sekolahnya. Pandangan dan perasaan siswa yang positif terhadap sekolah akan berhubungan positif dengan penerimaan siswa terhadap nilai-nilai pendidikan, motivasi belajar, dan komitmen di dalam sekolah (Goodenow \& Grady, dalam Karatzias, Power, \& Swanson, 2001), sebaliknya, pandangan dan perasaan negatif akan membuat siswa merasa tidak puas terhadap sekolah. Ketidakpuasan siswa terhadap sekolah memiliki hubungan positif dengan prestasi belajar yang buruk dan perilaku bermasalah di sekolah (Baker, dalam Karatzias, Power, \& Swanson, 2001), termasuk tidak disiplin. Hasil penelitian Leonard (2002) menemukan bahwa siswa yang menganggap sekolahnya sebagai tempat yang tidak menyenangkan, memiliki persepsi negatif terhadap seluruh aspek yang ada di sekolah, sementara siswa dengan kualitas kehidupan sekolah yang tinggi akan menunjukkan tingkat ketidakhadiran yang lebih rendah.

Hunt-Sartori (2007) juga menemukan bahwa persepsi siswa terkait kualitas kehidupan sekolah memiliki hubungan yang signifikan dengan rendahnya permasalahan disiplin dan tingginya kesuksesan akademik. Curelaru, Iacob, dan Abalasei (2009) mengungkapkan bahwa siswa yang mengalami kekerasan di sekolah akan rentan memiliki harga diri yang rendah, kesendirian, depresi, kecemasan, atau ketidakhadiran. Hal tersebut menunjukkan bahwa apabila kualitas kehidupan sekolah menunjukkan penurunan, maka dapat berpengaruh pada munculnya lebih banyak perilaku negatif pada siswa.

Berdasarkan uraian di atas tampak bahwa lingkungan sekolah, khususnya pesantren, merupakan salah satu lingkungan sosial sebagai tempat berkembangnya disiplin pada santri asrama. Pesantren adalah tempat untuk menimba ilmu dan pengetahuan, keterampilan, dan pengalaman yang diperoleh melalui proses belajar akan memberikan kontribusi yang sangat besar terhadap perkembangan dan pembentukan karakter santrinya sebagai bekal hidup di masa depan, sehingga pesantren haruslah menjadi tempat yang nyaman dan aman bagi para santri. Kondisi tersebut dipandang menarik dikaji lebih lanjut untuk menguji secara empiris 
hipotesis yang dirumuskan yakni terdapat hubungan positif antara kualitas kehidupan sekolah dengan disiplin pada santri asrama di Pondok Pesantren Pabelan.

\section{METODE}

Subjek dalam penelitian ini adalah santri asrama kelas VII, VIII, X, dan XI di Pondok Pesantren Pabelan. Metode pengumpulan data yang digunakan dalam penelitian ini adalah metode skala psikologi. Skala merupakan salah satu alat pengumpulan data untuk mengungkap aspek psikologis, berupa pertanyaan atau pernyataan yang secara tidak langsung mengungkap indikator perilaku dari atribut yang bersangkutan, dan respon subjek tidak diklasifikasikan sebagai jawaban benar atau salah (Azwar, 2005). Skala yang digunakan dalam penelitian ini adalah skala disiplin dan skala kualitas kehidupan sekolah.

Sistem penilaian dalam skala disiplin dan skala kualitas kehidupan sekolah menggunakan model likert yang terdiri dari empat kategori jawaban. Keempat pilihan jawaban tersebut, yaitu Sangat Sesuai (SS), Sesuai (S), Tidak Sesuai (TS), dan Sangat Tidak Sesuai (STS). Modifikasi skala dengan menghilangkan alternatif respon netral (N) dilakukan dengan alasan untuk mencegah alasan pengelakan (equivocation) atau mencegah subjek penelitian akan memilih respon netral sebagai cara untuk menghindari pilihan (DeVellis, 2011). Skala disiplin terdiri dari 22 aitem favorable dan 18 aitem unfavorable dengan koefisien alpha 0,915 . Skala kualitas kehidupan sekolah terdiri dari 17 aitem favorable dan 15 aitem unfavorable dengan koefisien alpha 0,903 . Kedua skala memiliki daya diskriminasi aitem $>0,30$.

Teknik analisis data yang digunakan dalam penelitian ini adalah analisis regresi (anareg) linier sederhana. Anareg linier sederhana adalah teknik statistik parametrik yang dapat digunakan untuk mengadakan prediksi besarnya variasi yang terjadi pada variabel dependen berdasarkan variabel independen, menentukan hubungan antara variabel independen dengan variabel dependen dan menentukan arah dan besarnya koefisien korelasi antara variabel independen dengan variabel dependen yang mempunyai hubungan linier (Winarsunu, 2006). Dalam penelitian ini analisis regresi digunakan untuk mengetahui hubungan, bentuk hubungan, serta arah dan besarnya koefisien korelasi antara kualitas kehidupan sekolah dan disiplin. Analisis dilakukan dengan bantuan SPSS 16.0 for Windows.

\section{HASIL DAN PEMBAHASAN}

Berdasarkan hasil uji normalitas yang diperoleh terhadap variabel disiplin didapatkan nilai Kolmogorov-Smirnov sebesar 0,878 dengan nilai $\mathrm{p}=0,424(\mathrm{p}>0,05)$. Hasil tersebut 
mengindikasikan bahwa sebaran data disiplin memiliki distribusi normal. Uji normalitas pada variabel kualitas kehidupan sekolah didapatkan nilai Kolmogorov-Smirnov sebesar 1,175 dengan nilai $\mathrm{p}=0,127(\mathrm{p}>0,05)$. Hasil tersebut mengindikasikan bahwa sebaran data kualitas kehidupan sekolah juga memiliki distribusi normal. Uji linieritas hubungan antara variabel kualitas kehidupan sekolah dengan variabel disiplin didapatkan hasil $\mathrm{F}_{\mathrm{Lin}}=47,897$ dengan signifikansi 0,000 ( $\mathrm{p}<0,01)$. Hasil ini menunjukkan bahwa hubungan antara kedua variabel tersebut adalah linier.

Kategorisasi skor subjek berdasar variabel disiplin dapat dilihat pada gambar berikut:

Tabel 1. Kategorisasi Skor Variabel Kedisiplinan

\begin{tabular}{|c|c|c|c|c|}
\hline $\begin{array}{l}\text { Sangat } \\
\text { Rendah }\end{array}$ & Rendah & Sedang & Tinggi & $\begin{array}{c}\text { Sangat } \\
\text { Tinggi }\end{array}$ \\
\hline 0 & 0 & 5 & 86 & 49 \\
\hline $0 \%$ & $0 \%$ & $3,57 \%$ & $\begin{array}{r}61,43 \% \\
110\end{array}$ & $\begin{array}{l}35 \% \\
130\end{array}$ \\
\hline
\end{tabular}

Kategorisasi skor subjek berdasar variabel kualitas kehidupan sekolah dapat dilihat pada gambar berikut:

Tabel 2. Kategorisasi Skor Variabel Kualitas Kehidupan Sekolah

\begin{tabular}{|c|c|c|c|c|}
\hline $\begin{array}{c}\text { Sangat } \\
\text { Rendah } \\
0\end{array}$ & $\begin{array}{c}\text { Rendah } \\
1\end{array}$ & $\begin{array}{c}\text { Sedang } \\
17\end{array}$ & $\begin{array}{c}\text { Tinggi } \\
87\end{array}$ & $\begin{array}{c}\text { Sangat } \\
\text { Tinggi } \\
35\end{array}$ \\
\hline $0 \%$ & $0,71 \%$ & $12,14 \%$ & $\begin{array}{c}62,14 \\
\%\end{array}$ & $25 \%$ \\
\hline & & 72 & & \\
\hline
\end{tabular}

Hasil yang diperoleh dari uji hipotesis dalam penelitian ini menunjukkan adanya hubungan positif yang signifikan antara kualitas kehidupan sekolah dengan disiplin pada santri asrama Pondok Pesantren Pabelan. Nilai $p=0,000 \quad(p<0,01)$ menunjukkan bahwa terdapat hubungan yang signifikan antara variabel kualitas kehidupan sekolah dengan disiplin pada santri asrama Pondok Pesantren Pabelan. Nilai koefisien korelasi $\left(\mathrm{r}_{\mathrm{xy}}\right)=0,508$ menunjukkan arah hubungan kedua variabel bersifat positif, yaitu semakin positif kualitas kehidupan sekolah yang dimiliki santri maka semakin tinggi tingkat disiplinnya, sebaliknya semakin negatif kualitas kehidupan sekolah yang dimiliki santri maka semakin rendah tingkat disiplinnya. Hasil tersebut menunjukkan bahwa hipotesis yang menyatakan bahwa terdapat hubungan positif antara kualitas kehidupan sekolah dengan disiplin diterima. Terujinya hipotesis ini menunjukkan bahwa kualitas kehidupan sekolah merupakan salah satu faktor yang menentukan disiplin pada santri.

Hasil penelitian menunjukkan bahwa pada saat dilakukan penelitian sebanyak 86 dari 140 santri $(61,43 \%)$ di Pondok Pesantren Pabelan yang menjadi subjek penelitian memiliki 
tingkat disiplin yang tinggi dengan mean empirik $(126,65)$ lebih besar dari mean hipotetik (100). Tingginya disiplin santri menunjukkan bahwa santri di Pondok Pesantren Pabelan memiliki pemahaman yang baik mengenai sistem aturan dan norma yang berlaku di pesantren, sehingga tumbuh kesadaran untuk taat pada peraturan dan norma tersebut. Pemahaman yang baik terhadap aturan berarti mengerti perlunya suatu nilai dari suatu peraturan dibuat dan perlu untuk dilakukan atau dipatuhi (Djojonegoro, dalam Soemarmo, 1998). Pemahaman yang baik terhadap aturan akan membawa santri bersedia menyesuaikan diri terhadap aturan pesantren, sehingga santri mudah untuk menginternalisasi nilai-nilai yang terkandung di dalam aturan-aturan yang berlaku di pesantren.

Disiplin pada santri asrama Pondok Pesantren Pabelan berada pada kategori tinggi, salah satunya dipengaruhi oleh kualitas kehidupan sekolah yang positif. Alasan tingginya disiplin pada santri asrama Pondok Pesantren Pabelan tersebut terkait dengan pandangan dan perasaan santri yang positif dalam menjalin hubungan dengan orang-orang yang ada di pesantren dan pengalaman-pengalaman positif selama berada di pesantren. Hasil penelitian sebelumnya yang dilakukan oleh Law dan Soleman (dalam Leonard, 2003) membuktikan bahwa pandangan dan perasaan negatif siswa terhadap sekolah akan mempengaruhi masalah-masalah yang muncul di sekolah, seperti perilaku tidak disiplin dan ketidakhadiran atau membolos. Siswa dengan pandangan dan perasaan negatif kemungkinan besar memiliki persepsi yang negatif terhadap hubungannya dengan guru dan teman sebaya, keberhasilan yang mungkin diperoleh dari sekolah, serta kegunaan sekolah untuk masa depannya.

Pandangan dan perasaan santri Pondok Pesantren Pabelan yang positif terhadap pesantren menunjukkan kualitas kehidupan sekolah yang dimiliki sebagian besar santri positif. Kualitas kehidupan sekolah yang dimiliki secara positif membuat para santri merasa memiliki keterikatan dan keterhubungan dengan pesantren, serta bersedia terlibat dalam berbagai aktivitas di pesantren. Keterhubungan dan keterlibatan yang dirasakan santri dapat mengurangi kemungkinan munculnya perilaku tidak disiplin pada santri-santri tersebut. McNeely, Nonnemaker, dan Blum (dalam Dupper, 2010) mengungkapkan bahwa keterikatan dan komitmen terhadap sekolah yang tinggi, serta keyakinan dalam aturan sekolah terkait dengan rendahnya tingkat kenakalan di sekolah. Hal senada diungkapkan Ozer (dalam Dupper, 2010) bahwa siswa yang merasa lebih terhubung dengan sekolah menunjukkan tingkat yang lebih rendah dalam gangguan emosi, perilaku tidak disiplin, dan agresi.

Hubungan positif antara siswa atau santri asrama dengan guru dan teman-teman sebayanya dapat meningkatkan keterhubungan siswa dengan sekolah dan disiplin kelas (Dupper, 2010). Guru memainkan peran penting dalam disiplin yang terjadi di sekolah 
umum. Guru sering membuat keputusan mengenai suatu kejadian di dalam kelas atau memberikan kebijakan mengenai pelanggaran terhadap disiplin yang terjadi di dalam kelas (Wald \& Casella, dalam Dupper, 2010). Berdasarkan hasil wawancara peneliti pada Juli 2012 di Pondok Pesantren Pabelan kapada pengasuh asrama, disiplin yang tinggi pada santri asrama Pondok Pesantren Pabelan didukung adanya hubungan yang positif antara santri dengan kyai, ustadz, dan teman-teman sesama santri yang berada di lingkungan pesantren. Pengasuhan kyai menangani pendidikan keluarga (informal) yang meliputi pengarahan, bimbingan, teguran, serta hal-hal yang berkaitan dengan pembinaan karakter dan kepribadian santri. Kyai sering memberi asuhan secara langsung kepada para santri, meskipun beliau tidak memberikan waktu tertentu dalam pelaksanaannya. Santri juga cukup dekat dengan beberapa ustadz, khususnya ustadz praktek, karena ustadz-ustadz tersebut sebelumnya juga adalah santri-santri senior yang pernah tinggal bersama dalam satu kamar asrama.

Santri asrama di Pondok Pesantren Pabelan terdiri dari kelas VII sampai IX Mts dan X sampai XII MA. Para santri menempati kompleks asrama yang terpisah antara santri putra dan putri. Satu kamar di asrama terdiri dari campuran santri dari kelas VII sampai XII. Kelas XII termasuk santri senior sekaligus sebagai pendamping kamar yang membimbing dan mengontrol santri yang lebih muda. Senior banyak memberikan pengarahan mengenai seluk beluk pesantren serta bagaimana kehidupan di lingkungan pesantren. Letak kamar yang berdekatan, membuat para santri dapat saling berinteraksi. Setiap kamar juga diberi kepercayaan untuk menyusun peraturan masing-masing, sehingga tanggung jawab dirasa lebih besar bagi para santri untuk melaksanakannya. Berbagai perlombaan juga ditujukan untuk setiap kamar, yang tujuannya untuk mempererat hubungan antar santri. Hubungan yang baik dengan kyai, ustadz, dan teman sesama santri membuat santri yang bersangkutan merasa memiliki keterikatan serta keterhubungan dengan orang-orang di pesantren. Keterhubungan dan keterlibatan yang dirasakan santri dapat mengurangi kemungkinan munculnya perilaku tidak disiplin pada santri. Kondisi tersebut sesuai dengan hasil penelitian McNeely, Nonnemaker, dan Blum (dalam Dupper, 2010) yang mengungkapkan bahwa keterikatan dan komitmen terhadap sekolah yang tinggi, serta keyakinan dalam aturan sekolah berpengaruh terhadap rendahnya tingkat kenakalan di sekolah.

Kualitas kehidupan sekolah yang positif pada santri juga didukung oleh adanya kesempatan yang diberikan pesantren yang berguna untuk masa depan santri serta perasaan berprestasi santri selama mengikuti pendidikan di pesantren. Kesempatan untuk megembangkan kemampuan santri disediakan pihak pesantren melalui Organisasi Pelajar Pondok (OPP) yang merupakan organisasi resmi pesantren yang mengelola seluruh kegiatan 
kesantrian selama santri berada di pesantren. Seperti yang dikemukakan Blandford (2005) bahwa kesempatan yang diberikan sekolah kepada siswa untuk mengembangkan diri dapat berpengaruh terhadap sikap dan perilaku yang ditampilkan siswa. Pesantren juga memberikan berbagai fasilitas kepada santri untuk mengembangkan segala potensi yang dimiliki, baik dalam kegiatan belajar mengajar maupun kegiatan ekstrkurikuler. Santri yang berprestasi akan memperoleh fasilitas khusus untuk memaksimalkan prestasi yang dimiliki, misalnya dikirim untuk mengikuti pertukaran pelajar American Field Services (AFS), jambore nasional, serta memperoleh penghargaan IAYP (Internasional Award for Young People).

Pesantren juga menyediakan sarana dan prasarana untuk menunjang kelancaran dan kenyamanan seluruh santri dalam mengikuti pendidikan di pesantren. Hal tersebut merupakan wujud dari keinginan pihak pesantren untuk mewujudkan suasana pesantren yang kondusif bagi perkembangan siswa di pesantren. Suasana lingkungan yang kondusif di sekolah dapat membuat siswa merasa aman dan nyaman saat berada di sekolah, dan kondisi tersebut dapat menurunkan perilaku buruk oleh siswa (Blandford, 2005). Demikian juga perasaan aman dan nyaman santri berada di pesantren membuat para santri merasa terhubung dengan pesantren, sehingga santri bersedia terlibat dalam berbagai aktivitas yang dilakukan di pesantren beserta ketentuan dan peraturan yang menyertai.

Data penelitian ini juga menunjukkan bahwa pada saat dilakukan penelitian sebanyak 87 dari 140 santri $(62,14 \%)$ di Pondok Pesantren Pabelan yang menjadi subjek penelitian memiliki kualitas kehidupan sekolah yang tinggi dengan mean empirik $(98,83)$ lebih besar dari mean hipotetik (80). Kondisi tersebut mengindikasikan bahwa rata-rata santri asrama di Pondok Pesantren Pabelan memiliki pengalaman yang positif dalam seluruh dimensi kehidupan di pesantren, meliputi hubungannya dengan teman sesama santri, ustadz, dan kyai, adanya kesempatan yang diberikan pihak pesantren yang akan berguna untuk masa depannya, perasaan berprestasi selama di pesantren, serta lingkungan pesantren yang memberikan rasa nyaman dalam beraktivitas.

Subjek dalam penelitian ini rata-rata memiliki kualitas kehidupan sekolah yang positif dan disiplin yang tinggi. Kualitas kehidupan sekolah memberikan sumbangan efektif sebesar 25,8\% terhadap disiplin pada santri asrama Pondok Pesantren Pabelan. Artinya masih ada $74,2 \%$ faktor lain yang dapat mempengaruhi disiplin yang tidak diungkap secara empirik dalam penelitian ini di antaranya faktor fisik, perkembangan, serta faktor dari luar individu yang berasal dari keluarga maupun masyarakat di lingkungan sekitar (Dupper, 2010). 


\section{KESIMPULAN}

Berdasarkan hasil penelitian yang telah dilakukan, dapat ditarik kesimpulan bahwa ada hubungan yang positif dan signifikan antara kualitas kehidupan sekolah dengan disiplin pada santri asrama Pondok Pesantren Pabelan. Hubungan yang positif mengindikasikan bahwa semakin positif kualitas kehidupan sekolah yang dimiliki santri, maka semakin tinggi pula disiplin. Sebaliknya, semakin negatif kualitas kehidupan sekolah yang dimiliki santri, maka semakin rendah pula disiplin. Kualitas kehidupan sekolah memberikan sumbangan efektif sebesar 25,8\% terhadap disiplin pada santri asrama Pondok Pesantren Pabelan, sedangkan $74,2 \%$ dipengaruhi oleh faktor lain yang tidak diungkap secara empirik dalam penelitian ini.

Berdasarkan hasil penelitian yang diperoleh, maka dapat dikemukakan saran-saran bagi santri, pihak pesantren, dan peneliti selanjutnya. Bagi santri diharapkan dapat mempertahankan penilaian yang positif terhadap pesantren, terutama dalam aktivitas yang dilakukan di pesantren dan berhubungan dengan aspek-aspek yang dimiliki pesantren, sehingga akan memicu santri untuk menampilkan tingkah laku yang sesuai dengan aturan yang berlaku di lingkungan pesantren. Bagi pihak Pesantren diharapkan meningkatkan keterlibatan pengasuh dan pengurus dalam berbagai kagiatan santri sehingga dapat memberikan keteladanan melalui contoh-contoh penerapan disiplin dalam kehidupan seharihari, sekaligus sebagai upaya untuk menjalin hubungan positif dengan santri. Upaya tersebut diharapkan dapat mewujudkan disiplin secara keseluruhan di lingkungan pesantren. Bagi peneliti selanjutnya yang tertarik meneliti tentang kedisiplinan disarankan untuk meneliti variabel lain yang diduga turut mempengaruhi kedisiplinan seperti iklim sekolah, pola asuh orangtua, dan pengaruh sosial budaya. Peneliti selanjutnya juga dapat menggunakan pendekatan kualitatif untuk memperoleh data yang lebih spesifik yang tidak dapat diungkap secara kuantitatif, misalnya melihat santri yang bermasalah atau memiliki tingkat pelanggaran yang sangat tinggi di pesantren.

\section{DAFTAR PUSTAKA}

Atifah, N. (2006). Hubungan tingkat kedisiplinan dengan prestasi belajar sosiologi bagi siswa kelas xi ips madrasah aliyah negeri babakan lebaksiu tegal. Skripsi. Semarang: Universitas Negeri Semarang.

Azwar, S. (2005). Metode Penelitian. Yogyakarta: Pustaka Pelajar.

Bagley, W. C. (2010). School Discipline. New York: Macmillan Company.

Blandford, S. (2005). Managing discipline in school. London: Routledge. 
Curelaru, M., Iacob, I., \& Abalasei, B. (2009). School bullying: Definition, characteristics, and intervention strategies. Revista de Cercetare si Interventie Sociala, 26, 7-29.

DeVellis, R. F. (2011). Scale development: Theory and applications (3th ed.). Los Angeles: Sage Publications.

Dewi, I. (2010). Pengaruh pelatihan kedisiplinan dalam meningkatkan disiplin belajar siswa di sekolah menengah pertama. Tesis. Yogyakarta: Universitas Gadjah Mada.

Djamarah, S. B. (2008). Rahasia Sukses Belajar. Jakarta: Rineka Cipta.

Dupper, D. R. (2010). A new model of school discipline : Engaging students and preventing behavior problems. New York: Oxford University Press.

Handayani, R. W. (2007). Penanaman disiplin dalam mentaati peraturan dan tata tertib. Skripsi. Semarang: Universitas Negeri Semarang.

Huda, M. (2014). Model pendidikan karakter dalam rangka peningkatan sikap disiplin pada siswa-siswa kelas VII MTs Negeri Sampung Ponorogo. Skripsi. Ponorogo: Universitas Muhammadiyah Ponorogo.

Hunt-Sartori, M. A. (2007). The relationships among student membership in groups quality of school life, sense of belonging and selected performance factors. Dissertation. Huntsville Texas: Sam Houston State University.

Johnson, W. L., \& Johnson, A. M. (1993). Validity of the quality of school life scale: A primary and second-order factor analysis. Educational and Psychological Measurement, 53, 145-153.

Karatzias, A., Power, K. G., \& Swanson, V. (2001). Quality of school life: A cross-cultural study of Greek and Scottish secondary school pupils. European Journal of Educationn, $36(1), 91-105$.

Kwong, K. C. (2006). Classroom learning experiences and students' perceptions of quality of school life. Hong Kong: Chinese University of Hong Kong.

Lemhannas. (1997). Disiplin Nasional. Jakarta: Balai Pustaka.

Leonard, C. (2003). Affective outcomes in the context of school reform. Newcastle: University of Newcastle.

(2002). Quality of school life and attendance in primary school. Newcastle: University of Newcastle.

Mu'tasim, R., dkk. (2005). Profil 40 tahun pondok pesantren pabelan 1965-2005. Muntilan: Pondok Pesantren Pabelan.

Nurhasan, A., \& Suyanto, W. (2014). Peranan perhatian orangtua terhadap kedisiplinan belajar pada siswa kelas XI program keahlian otomotif SMK Muhammadiyah 1 Salam. Skripsi. Yogyakarta: Universitas Negeri Yogyakarta. 
Octyavera, R. M. (2006). Hubungan kualitas kehidupan sekolah dengan penyesuaian sosial pada siswa sma international islamic boarding school republic of Indonesia. Skripsi. Semarang: Universitas Diponegoro.

Qomar, M. (2006). Pesantren dari transformasi metodologi menuju demokratisasi institusi. Jakarta: Erlangga.

Rahman, S. H. (2016). Implementasi peraturan sekolah dalam meningkatkan kedisiplinan guru dan siswa. Tesis. Malang: Universitas Islam Negeri Maulana Malik Ibrahim.

Rogers, B. (2011). You know the fair rule: Strategies for positive and effective behaviour management and discipline in school. Camberwell: ACER Press.

Setyorini, D. E. (2016). Pengaruh ekstrakurikuler kepramukaan terhadap kedisiplinan siswa SD Negeri Gugus Cakra Kecamatan Ngaliyan Kota Semarang. Skripsi. Semarang: Universitas Negeri Semarang.

Sochib, M. (2010). Pola Asuh Orangtua dalam Membantu Anak Mengembangkan Disiplin Diri. Jakarta: Rineka Cipta.

Soemarmo. (1998). Pedoman pelaksanaan disiplin nasional dan tata tertib sekolah. Jakarta: CV Mini Jaya Abadi.

Thien, L. M., \& Razak, N. A. (2012). Academic coping, friendship quality, and student engagement associated with student quality of school life: A partial least square analysis. Soc Indic Res, 112, 679-708.

Triastuti, W. (2015). Pengaruh pemberian sanksi terhadap kedisiplinan dalam mematuhi tata tertib sekolah di MIN Kragan Kecamatan Gondangrejo Kabupaten Karanganyar Tahun Ajaran 2014/2015. Naskah Publikasi. Surakarta: Universitas Muhammadiyah Surakarta.

Wahyuni, T. (2012). Pengaruh perhatian orangtua terhadap kedisiplinan belajar siswa di Sekolah Menengah Atas Negeri 12 Pekanbaru. Skripsi. Pekanbaru: Universitas Islam Negeri Sultan Syarif Kasim Riau.

Weintraub, N., Erez, A. B. (2009). Quality of life in school (QoLS) questionnaire: Development and validity. The American Journal of Occupational Therapy, 63 (6), 724-731.

Winarsunu, T. (2006). Statistik dalam penelitian psikologi dan pendidikan (edisi revisi). Malang: UMM Press.

Yudiastri, F. I., Yusmansyah, \& Rahmayanthi, R. (2015). Peningkatan disiplin siswa menggunakan konselingkelompok pendekatan behavior siswa SMP kelas VIII. Jurnal Bimbingan Konseling, 4 (2), 1-15.

Zulbina, \& Sailan, M. (2015). Peningkatan kedisiplinan siswa melalui gerakan pramuka pada SMA Muhammadiyah Kalosi kec. Alla Kabupaten Enrekang. Skripsi. Makassar: Universitas Negeri Makasar. 